\title{
SOCIO-ECONOMIC AND ORGANIZATIONAL FACTORS OF POULTRY FARMING DEVELOPMENT IN THE UKRAINIAN SSR IN 1964-1971
}

\section{Victoriia Melnyk}

\section{INTRODUCTION}

Public interest in the history of science, reassessment of existing stereotypes require a detailed inventory and rethinking of the depths of advanced scientific experience in the field of poultry, the use of which can be especially relevant when finding effective ways of further development of this field. The Ukrainian scientists have achieved considerable success both in the development of conceptual provisions of breeding and selection of agricultural poultry, as well as its feeding and keeping, established reputable scientific schools. In the early 60's of the 20th century already considerable experience of poultry enterprises working in countries abroad, including the USA ${ }^{1}$, France $^{2}$, $\mathrm{Japan}^{3}, \mathrm{USSR}^{4}$ and the Ukrainian $\mathrm{SSR}^{5}$. The need for research of industry priority achievements and creative achievements in the Ukrainian SSR in the 60's - early 70's of the 20th century. It is also conditioned by the fact that on the path of the history of poultry farming it was marked as a transition stage from extensive production to introduction of industrial high-intensity technologies, which provided

\footnotetext{
${ }^{1}$ Dahnovskij, N. V. (1959) Intensivnoe pticevodstvo v Soedinennyh Shtatah Ameriki [Intensive poultry farming in the United States]. Moscow, 127 s. (in Russian).

${ }^{2}$ Aleksandrov, A. D. (1960) Pticevodstvo vo Francii [Poultry in France]. Pticevodstvo, no. 11, pp. 45-47 (in Russian).

${ }^{3}$ Bozhko, P. E. (1963) Pticevodstvo Japonii [Poultry of Japan]. Pticevodstvo, no. № 9, pp. 30-32 (in Russian).

${ }^{4}$ Krjazh, I. Z. (1960) Opyt vyrashhivanija mjasnyh cypljat $v$ hozjajstvah Bol'sheNovoselkovskogo rajona [The experience of growing meat chickens in farms BolsheNovoselkovsky district]. Pticevodstvo, no. 8. S. 10-13 (in Russian).

${ }^{5}$ Samoletov, A. I., \& Karavaev, A. M. (1960). Kletochnoe soderzhanie kurnesushek na Tomilinskoj pticefabrike [Cage content of laying hens at Tomilinsky poultry farm]. Pticevodstvo, no. 8, pp. 6-10. (in Russian); Shajtan, B. I., \& Polishhuk, P. N. (1960) Organizacija pticevodstva v kolhoze «Kolos» [The organization of poultry farming at collective farm Kolos]. Pticevodstvo, no. 5, pp. 4-10 (in Russian).
} 
qualitative and quantitative growth of production of poultry products. Special literature provides information on the state of industrial poultry farming in the USSR during the period 1964-1971 ${ }^{6}$.

In our previous explorations, the scientific and organizational factors of the development of duck, goose and turkey breeding in the Ukrainian SSR in the second half of the 20th century are revealed ${ }^{7}$. However, due attention has not been paid to the study of the socioeconomic and organizational foundations of poultry development in the Ukrainian SSR in the period 1964-1971, which was marked by its transfer to an industrial basis.

The purpose of the work is to highlight the socio-economic and organizational factors of the formation and development of the industrial poultry sector in the Ukrainian SSR in 1964-1971.

\footnotetext{
${ }^{6}$ Pushkarenko, V., Lilevman, V. (1966). Kletochnaja batareja dlja vyrashhivanija utjat do 10 dnej [Cage battery for duckling for up to 10 days]. Pticevodstvo, no. 3 , pp. 27-29. (in Russian); Hachirashvili, G., \& Shperling, M. (1966) Kul'tura proizvodstva - osnova uspeha [The culture of production is the basis of success]. Pticevodstvo, no. 10, pp.4-9. (in Russian); Sergeev, V., Popov, A. (1970). Proizvodstvo mjasa brojlerov na kolhoznyh fermah [Production of broiler meat on collective farms]. Pticevodstvo, no. 9, pp. 14-15. (in Russian); Poplevkin, T. (1970) Mjasnoe pticevodstvo Ukrainy na podeme [Ukrainian meat poultry farming on the rise]. Pticevodstvo, no. 9, pp. 2-3.

${ }^{7}$ Meljnyk, V. V. (2018) Orghanizacijno-metodychna ta koordynacijna dijaljnistj Ukrajinsjkogho respublikansjkogho specializovanogho trestu ptakhofabryk $i$ ptakhoradghospiv v 1963-1964 rokakh [Organizational-methodical and coordination activity of the Ukrainian Republican Specialized Trust of Poultry Factories and Poultry Farms in 1963-1964]. Istorija nauky $i$ bioghrafistyka [History of Science and Biography Studies]: elektron. nauk. fakhove vyd, no. 3. URL: http://inb.dnsgb.com.ua/ 2018-3/07.pd. Accessed 25.05. 2018. (in Ukrainian); Meljnyk, V. V. (2018) Naukovoorghanizacijni zasady rozvytku indykivnyctva $v$ Ukrajinsjkij RSR u drughij polovyni $X X$ stolittja [Scientific and organizational principles of the development of turkey farming in the Ukrainian SSR in the second half of the twentieth century]. Ghileja: naukovyj visnyk, vyp. 135(N8), pp.67-71. (in Ukrainian); Meljnyk, V. V. (2018) Naukovo-orghanizacijni zasady rozvytku ghusivnyctva $v$ URSR u drughij polovyni $X X$ stolittja [Scientific and organizational principles of geese farming development in the Ukrainian SSR in the second half of the twentieth century]. Visnyk aghrarnoji istoriji: nauk. Zhurnal, vyp. 23-24, pp. 282-289. (in Ukrainian); Meljnyk, V. V. (2018) Naukovo-orghanizacijni zasady rozvytku kachkivnyctva $v$ Ukrajinsjkij RSR u drughij polovyni XX stolittja. [Scientific and organizational principles of duck farming development in the Ukrainian SSR in the second half of the twentieth century]. Eminak: naukovyj shhokvartaljnyk, no. 4(24), vol. 2, pp. 177-181. (in Ukrainian).
} 


\section{Socio-economic factors of poultry development in the Ukrainian SSR in 1964-1971}

Production of poultry products in the USSR in the early 60's of the last century was concentrated in the public sector and in households. If in $196115 \%$ of the total number of eggs were produced in state-owned enterprises of the USSR, then in 1964 this figure increased to $17 \%^{8}$. According to statistics, the rest of the eggs were produced in farms of the rural population. Due to the rapid growth of urban population in the USSR and the Ukrainian SSR in the second half of the 20th century, there was an urgent problem of providing urban residents with food. As noted in our previous publications, its percentage in 1952 was 39, and as of January 1, 1963, it increased to $50^{9}$. In this regard, in January 1963 approved the resolution of the CPSU Central Committee and the Council of Ministers of the USSR "On the increase in production of eggs and poultry in suburban areas of large cities and industrial centers", which preceded the resolution adopted in 1964 by the CPSU Central Committee and Council of Ministers of the USSR "On the Organization of Production of Eggs and Poultry Meat on an Industrial Basis" $"$. In accordance with their decisions, the Council of Ministers of the Union Republics and the State Building of the USSR pledged to ensure the commissioning of poultry farms and poultry farms with an annual capacity of enterprises for 20-40 million eggs or 1-2 million

${ }^{8}$ Statistika, (1965). Narodne ghospodarstvo Ukrajinsjkoji RSR v 1964 roci: statystychnyj shhorichnyk [People's economy of the Ukrainian SSR in 1964: statistical yearbook]. Kyiv, 694 s. (in Ukrainian).

${ }^{9}$ Meljnyk, V. V. (2017) Socialjno-ekonomichni ta politychni peredumovy stanovlennja promyslovogho ptakhivnyctva v USSR (1953-1964). [Socio-economic and political preconditions for the establishment of industrial poultry farming in the Ukrainian SSR (1953-1964)]. Istorija nauky i bioghrafistyka [History of Science and Biography Studies]: elektron. nauk. fakhove vyd, no. 2 URL: http://inb.dnsgb.com.ua/ 2017-2/07.pd. Accessed 15.04. 2018 (in Ukrainian).

${ }^{10}$ Izvestija, (1985). Ob uvelichenii, 1985 - Ob uvelichenii proizvodstva jaic i mjasa pticy $v$ prigorodnyh zonah krupnyh gorodov i promyshlennyh centrov: Postanovlenie Central'nogo Komiteta KPSS $i$ Soveta ministrov SSSR ot 8 janvarja $1963 \mathrm{~g}$. [On increasing the production of eggs and poultry meat in the suburban areas of major cities and industrial centers: Resolution of the Central Committee of the CPSU and the Council of Ministers of the USSR of January 8, 1963], № 30. Svod zakonov SSSR. Moscow, vol. 7, pp. 519-520. (in Russian). 
broilers for one and a half or two years, and more - within two to three years from the beginning of construction. Decisions were made to organize the USSR Poultry Industry Department to manage specialized poultry farms, and in the Union republics the poultry industry departments or poultry trusts ${ }^{11}$. It should be noted that prior to the establishment of the Department of the Poultry Industry of the USSR, the coordination of this work was carried out by the Ukrainian Republican specialized trust of poultry farms and poultry farms, whose organizational and methodical activity in 1963-1964 was covered in the article. Poultry industry of the Ukrainian SSR, poultry industry management and poultry trusts of the Union republics performed the following functions:

1) production of eggs and poultry meat on an industrial basis, implementation of plans for sale to the state of these products by poultry enterprises;

2) organization of breeding, hybridization of poultry, breeding work in poultry farms and in the network of specialized farms, provision of poultry farms and farms with high-performance breeding and hybrid poultry;

3) development of compound feed recipes, control over production organization and quality of compound feed for poultry and ensuring its effective use;

4) introduction of advanced methods of organization of industrial poultry farming and modern technology of egg incubation, technology of keeping and care of poultry, as well as technology of poultry processing;

5) search for the most rational forms of organization and normalization of labor, wide introduction of mechanization of production processes;

${ }^{11}$ Meljnyk, V. V. (2018) Orghanizacijno-metodychna ta koordynacijna dijaljnistj Ukrajinsjkogho respublikansjkogho specializovanogho trestu ptakhofabryk $i$ ptakhoradghospiv $v$ 1963-1964 rokakh [Organizational-methodical and coordination activity of the Ukrainian Republican Specialized Trust of Poultry Factories and Poultry Farms in 1963-1964]. Istorija nauky i bioghrafistyka [History of Science and Biography Studies]: elektron. nauk. fakhove vyd, no. 3. URL: http://inb.dnsgb.com.ua/20183/07.pd. Accessed 25.05. 2018. (in Ukrainian). 
6) selection and placement of management personnel and specialists, training of poultry experts, as well as upgrading the skills of poultry workers;

7) approval in the prescribed manner of the structure and typical staffs of poultry farms, poultry farms, breeding farms, poultry stations and other enterprises and organizations ${ }^{12}$.

As a result of our research, in the Ukrainian SSR, industrial poultry farming was developing at a rapid pace, along with the development of the entire economy. According to statistics, gross industrial production in 1971 increased by 1.6 times compared to 1965 , and agriculture by 1.2 times $^{13}$. In 1971 , relative to 1965 , the capital investments of state and cooperative enterprises increased by $146 \%$, the gross public product - by $148 \%$, the national income - by $146 \%$, the average wages of workers and employees - by $126 \%$, the wages of collective farmers - by $142 \%{ }^{14}$. Production per capita increased as well. Thus, in 1965, 153 eggs were produced, and in 1970 - 195 per capita, respectively, of meat of all types 49 and $60 \mathrm{~kg}^{15}$. Due to the increasing trend of urban population growth in the Ukrainian SSR in the 1970's (in 1971 it was $56 \%$ of the total population), it was decided to accelerate the organization of production of eggs and poultry on an industrial basis ${ }^{16}$. Large-scale poultry farms, as well as specialized

${ }^{12}$ Izvestija, (1985). Ob organizacii proizvodstva jaic i mjasa pticy na promyshlennoj osnove: Postanovlenie Soveta Ministrov SSSR i Central'nogo Komiteta KPSS ot 3 sentjabrja $1964 \mathrm{~g}$. [On the organization of the production of eggs and poultry meat on an industrial basis: Resolution of the Council of Ministers of the USSR and the Central Committee of the CPSU of September 3, 1964], № 740. Svod zakonov SSSR. Moscow, vol. 7, pp. 512-517. (in Russian).

${ }^{13}$ Statistika, (1976). Narodnoe hozjajstvo Ukrainskoj SSR v 1975 godu: statisticheskij ezhegodnik [People's Economy of the Ukrainian SSR in 1975: a statistical yearbook]. Kiev, 540 s. (in Russian).

${ }^{14}$ Statistika, (1974). Narodnoe hozjajstvo Ukrainskoj SSR v 1973 godu: statisticheskij ezhegodnik [People's Economy of the Ukrainian SSR in 1973: a statistical yearbook]. Kiev, 584 s. (in Russian).

${ }^{15}$ Statistika, (1976). Narodnoe hozjajstvo Ukrainskoj SSR v 1975 godu: statisticheskij ezhegodnik [People's Economy of the Ukrainian SSR in 1975: a statistical yearbook]. Kiev, 540 s. (in Russian).

16 Statistika, (1976). Narodnoe hozjajstvo Ukrainskoj SSR v 1975 godu: statisticheskij ezhegodnik [People's Economy of the Ukrainian SSR in 1975: a statistical yearbook]. Kiev, 540 s. (in Russian). 
farms became the organizational form of intensive industrial poultry farming. One of the largest poultry farms not only in the Ukrainian SSR, but also in the USSR, which specialized in the production of chicken food eggs, became the poultry farm "Yuzna" of the Crimean region, organized in 1965 on the basis of the state farm "Yuzhnyi". The farm was created in 1960 on the basis of the merger of three multisectoral farms. In the "Yuzhnyi" State Farm, besides poultry, they kept cattle, pigs, sheep, engaged in grain production, horticulture, viticulture, tobacco, and cultivation of essential oil crops ${ }^{17}$. The names of workers of this poultry farm A. Hetman, V. Kozina, M. Stocklos, M. Sidelnikov and others, who served thousands of laying hens in cage batteries, provided high livestock conservation and productivity, became known far beyond the Ukrainian SSR ${ }^{18}$. The management of the poultry farm was carried out by Director G. Khachirashvili, based on the strengthening of the role of economic methods of management, improvement of planning, expansion of economic autonomy and initiatives of the collectives of enterprises, increase of its material interest $^{19}$.

In the Ukrainian SSR of the studied period, egg poultry intensively developed. During five years after the official transfer of the industry to the industrial base in the country, 17 egg production poultry farms were built. The number of laying hens from 1966 to 1972 increased by 1.7 times in collective farms, state farms and other state-owned enterprises of the Ukrainian SSR, which resulted in a 3.6-fold increase in the production of poultry eggs ${ }^{20}$. It should be noted that among the Soviet republics of the USSR, the greatest successes in the development of meat poultry during the period under review were the Ukrainian

\footnotetext{
${ }^{17}$ Hachirashvili, G., \& Shperling, M. (1966) Ukrepljat' tehnologicheskuju disciplinu, povyshat' rentabel'nost' proizvodstva [Strengthen technological discipline, increase the profitability of production]. Pticevodstvo, no. 1, pp. 7-9. (in Russian).

${ }^{18} \mathrm{~V}$ kollektive geroev [In the team of heroes]. (1966) Pticevodstvo, no. 10. S. 2-4. (in Russian).

${ }^{19}$ Hachirashvili, G., \& Shperling, M. (1966) Ukrepljat' tehnologicheskuju disciplinu, povyshat' rentabel'nost' proizvodstva [Strengthen technological discipline, increase the profitability of production]. Pticevodstvo, no. 1, pp. 7-9. (in Russian).

${ }^{20}$ Statistika, (1974). Narodnoe hozjajstvo Ukrainskoj SSR v 1973 godu: statisticheskij ezhegodnik [People's Economy of the Ukrainian SSR in 1973: a statistical yearbook]. Kiev, 584 s. (in Russian).
} 
SSR. This was facilitated by the commissioning of five poultry farms of productivity in the system of the Main Poultry Trust in the Ukrainian $\mathrm{SSR}^{21}$. As a result of using their facilities and attracting other reserves of poultry farming, the production of poultry meat increased by 1.9 times from 1964 to $1971^{22}$. Already during this period, it became apparent that significant reserves for increasing poultry meat production were precisely in broiler production. With a view to its development, in 1962 the state farm "Krasnyi" (Crimean region) put into operation the first, not only in the Ukrainian SSR, but also in the USSR, an experimental broiler factory for the production of poultry meat on an industrial basis ${ }^{23}$. The poultry farm was restructured to produce poultry meat for meat production. For the first time in the Crimean region a complex of highly specialized farms was created in the Ukrainian SSR, which worked according to the plan of a single technological process on the basis of industrial cooperation ${ }^{24}$. Scientific and organizational support for the development of meat poultry breeding in the USSR was carried out by scientists of the Ukrainian Poultry Research Station, which in 1959 was reorganized into the Ukrainian Research Institute of Poultry Breeding by the order of the Ukrainian Academy of Agricultural Sciences ${ }^{25}$.

\section{Organizational factors of poultry development in the Ukrainian SSR of study period}

Scientists of the Crimean Branch of the Ukrainian Poultry Research Institute together with the collective of specialists of the state

${ }^{21}$ Kirin, I. (1970) Puti uvelichenija proizvodstva mjasa pticy [Ways to increase poultry production]. Pticevodstvo, no. 10, pp. 13-14. (in Russian).

${ }^{22}$ Statistika, (1966). Narodne ghospodarstvo Ukrajinsjkoji RSR v 1965 roci: statystychnyj shhorichnyk [People's economy of the Ukrainian SSR in 1965: statistical yearbook]. Kyiv, 715 s. (in Ukrainian).

${ }^{23}$ Marchik, V., \& Bronfman, E. (1970) Brojlernaja fabrika $v$ sodruzhestve $s$ kolhozami [Broiler factory in cooperation with collective farms]. Pticevodstvo, no. 9, pp. 12-13. (in Russian).

${ }^{24}$ Poplevkin, T. (1970) Mjasnoe pticevodstvo Ukrainy na pod eme [Ukrainian meat poultry farming on the rise]. Pticevodstvo, no. 9, pp. 2-3.

${ }^{25}$ Centraljnyj derzhavnyj arkhiv vyshhykh orghaniv vlady [Central State Archive of the Supreme Power and Administration of Ukraine], f. P-4861, d. 1, c. 2139, pp. 84-89. (in Ukrainian). 
farm "Krasnyi" for the first time in the Soviet Union developed the technology of growing broiler chickens, which in the future worked almost all poultry farms in the Ukrainian SSR. As it was developed on the farm, broiler meat production increased and financial performance improved. Thus, from 1967 to 1969, meat production in the state farm Krasnyi increased by $29.3 \%$ and the profitability of production 5.8 times $^{26}$. At the initiative and direct participation of the staff of the Ukrainian Poultry Research Institute and specialists of the state farm "Krasnyi" in the collective farm "Progress" of the Pavlograd region of Dnipropetrovsk region in 1968 broiler production was organized on an industrial basis, and in 1969 broiler production was decided on farms of the Crimean region ${ }^{27}$. At the same time, they provided practical assistance to collective and state farms on the supply of hybrid eggs from high-performance meat lines of chickens, developed compound feeds for broilers, issued scientific and practical recommendations on the technology of production of broiler meat, training of poultry. Thus, in 1970 on the basis of the state farm "Krasnyi" seminars for zootechnics of collective farms and hatchery-poultry stations of the Crimean region were held, at which more than 30 representatives from 6 collective farms underwent 20-day training ${ }^{28}$.

Successful development of poultry in the Ukrainian SSR after its transfer to the industrial base, had a positive impact on the socioeconomic status of the population. So, for example, in the republic at that time meat for catering and sale to workers and employees of state farms was released on limits from the state resources which were available to areas for delivery to the population. In 1969, the planned cost of poultry (chicken) in the system of the Ministry of State Farms of the USSR was lower than its retail price by $11.3 \%$. They implemented it for catering and sale to workers and employees of state farms at the

\footnotetext{
${ }^{26}$ Marchik, V., \& Bronfman, E. (1970) Brojlernaja fabrika $v$ sodruzhestve $s$ kolhozami [Broiler factory in cooperation with collective farms]. Pticevodstvo, no. 9, pp. 12-13. (in Russian).

${ }^{27}$ Sergeev, V., Popov, A. (1970). Proizvodstvo mjasa brojlerov na kolhoznyh fermah [Production of broiler meat on collective farms]. Pticevodstvo, no. 9, pp. 14-15. (in Russian).

${ }^{28}$ Marchik, V., \& Bronfman, E. (1970) Brojlernaja fabrika $v$ sodruzhestve $s$ kolhozami [Broiler factory in cooperation with collective farms]. Pticevodstvo, no. 9, pp. 12-13. (in Russian).
} 
planned $\operatorname{cost}^{29}$. This testified to the high economic efficiency of chicken production in farms. However, according to archival documents, the meat used in state farms for catering and sale, by its quality was much worse than that handed over to the state, this is explained by the fact that state farms sold a large part of the meat from forced slaughter animals $^{30}$.

We have found that for the production of poultry meat in the USSR, reserves duck, turkey were used ${ }^{31}$. Specifically, poultry in the republic was considered an important reserve for the industrial production of poultry meat. The rapid development of this industry in the USSR was facilitated by the popularization of the experience of the Yagotin Poultry Factory (Kyiv region), where for the first time they mastered the technology of growing ducklings for meat without the use of reservoirs. This poultry farm has become a school of excellence in the implementation of industrial breeding ${ }^{32}$. In 1965, a mechanized cage battery for growing ducklings up to 10 days of age was first manufactured and tested by the specialists of the South Ukrainian State Zonal Machine-Building Station (Kherson). Previously, ducklings were grown in cage batteries intended for growing chickens ${ }^{33}$.

${ }^{29}$ Centraljnyj derzhavnyj arkhiv vyshhykh orghaniv vlady [Central State Archive of the Supreme Power and Administration of Ukraine], f. P-2, d. 13, c. 5088, pp. 72-75. (in Ukrainian).

${ }^{30}$ Centraljnyj derzhavnyj arkhiv vyshhykh orghaniv vlady [Central State Archive of the Supreme Power and Administration of Ukraine], f. P-2, d. 13, c. 5088, pp. 72-75. (in Ukrainian).

${ }^{31}$ Meljnyk, V. V. (2018) Naukovo-orghanizacijni zasady rozvytku ghusivnyctva $v$ URSR u drughij polovyni XX stolittja [Scientific and organizational principles of geese farming development in the Ukrainian SSR in the second half of the twentieth century]. Visnyk aghrarnoji istoriji: nauk. zhurnal, vyp. 23-24, pp. 282-289. (in Ukrainian); Meljnyk, V. V. (2018) Naukovo-orghanizacijni zasady rozvytku indykivnyctva $v$ Ukrajinsjkij RSR u drughij polovyni XX stolittja [Scientific and organizational principles of the development of turkey farming in the Ukrainian SSR in the second half of the twentieth century]. Ghileja: naukovyj visnyk, vyp. 135(N8), pp. 67-71. (in Ukrainian).

${ }^{32}$ Kirin, I. (1970) Puti uvelichenija proizvodstva mjasa pticy [Ways to increase poultry production]. Pticevodstvo, no. 10, pp. 13-14. (in Russian).

${ }^{33}$ Pushkarenko, V., Lilevman, V. (1966). Kletochnaja batareja dlja vyrashhivanija utjat do 10 dnej [Cage battery for duckling for up to 10 days]. Pticevodstvo, no. 3, pp. 27-29. (in Russian). 
In general, these measures helped to increase the production of poultry meat, and mobilized a meat poultry reserve such as duckling. And, if in the system of farms of the Main Poultry Trust of the Ukrainian SSR in 1964 the share of duck meat production from the total production of poultry meat was 25\%, then in 1969 this figure increased to $41 \%{ }^{34}$. An important role in the development of industrial poultry in the Ukrainian SSR, like the entire USSR, was played by the 13th World Poultry Congress, held in Kiev on August 15, 1966 ${ }^{35}$. It facilitated friendly relations between poultry breeders from all over the world, strengthened business contacts and improved the exchange of scientific information. We found that during the study period there was an increase in concentration of production with advanced specialization, which improved the organization of technological process, labor, allowed better use of feed, which in general provided an increase in production of poultry products and a decrease in its cost. Thus, as of January 1, 1970, 820 farms in the Ukrainian SSR specialized in the production of eggs and poultry, including the production of eggs 745 and meat $-75^{36}$. Resolution of the Central Committee of the CPSU and the Council of Ministers of the USSR of July 16, 1970, decided to increase the production of full-fledged and cheap animal feeds by increasing the production of grain forage crops and increasing crop yields, as well as expanding the acreage of corn, legumes, soybeans and other crops in in areas where they produce high yields ${ }^{37}$. This decision was also important for the development of industrial poultry farming in the Ukrainian SSR, as the provision of full-fledged poultry feeds in farms has become a key chain in the

\footnotetext{
${ }^{34}$ Kirin, I. (1970) Puti uvelichenija proizvodstva mjasa pticy [Ways to increase poultry production]. Pticevodstvo, no. 10, pp. 13-14. (in Russian).

${ }^{35}$ Forum pticevodov [Forum poultry breeders]. (1966). Pticevodstvo, no. 5, pp. 10-11. (in Russian).

${ }^{36}$ Centraljnyj derzhavnyj arkhiv vyshhykh orghaniv vlady [Central State Archive of the Supreme Power and Administration of Ukraine], f. P-2, d. 13, c. 5088, pp. 72-75. (in Ukrainian).

${ }^{37}$ Izvestija, (1985). O merah po uvelicheniju proizvodstva i uluchsheniju kachestva kormov. Postanovlenie Central'nogo Komiteta KPSS $i$ Soveta Ministrov SSSR ot 16 ijulja $1970 \mathrm{~g}$. [On measures to increase production and improve the quality of feed. Resolution of the Central Committee of the CPSU and the Council of Ministers of the USSR of July 16, 1970], № 554. Svod zakonov SSSR. Moscow, vol. 7, pp. 530-531. (in Russian).
} 
production of eggs and meat. There was a need to put into operation new poultry farms and other state poultry farms, to introduce advanced technologies for the intensification of the poultry industry. In this regard, a decree was adopted in 1971: "Measures to further increase the production of eggs and poultry on an industrial basis". According to its decisions, it was required to use lightweight prefabricated and other modern designs of industrial poultry farming for poultry construction. One of the important points of the resolution is the obligation of the Council of Ministers of the Union Republics to establish annual tasks for the removal of young poultry at state and inter-farm poultry stations and poultry farms for the purpose of full provision of collective farms, livestock farms ${ }^{38}$. First of all, it was envisaged to create favorable conditions for the further accelerated construction of new poultry houses, the use of full-fledged compound feeds in poultry feeding, which allowed to apply complex mechanization and reduce labor costs for production of eggs and poultry meat. All these organizational measures were aimed at increasing the production of poultry products in order to provide the population with dietary food.

\section{CONCLUSIONS}

Thus, the formation and development of industrial poultry in the Ukrainian SSR in 1964-1971 was provided with favorable socioeconomic and organizational factors. The development of the industry occurred simultaneously with the rise of industry and the growth of gross public product, national income, wages of workers, employees and collective farmers, etc. The number of urban population was increasing, which became one of the prerequisites for the establishment of specialized industrial farms around the big cities and industrial centers of the republic - poultry farms for supplying the population with eggs and poultry meat. The production of poultry products was also organized on specialized farms of collective farms. During this

\footnotetext{
${ }^{38}$ Izvestija, (1985). O merah po dal'nejshemu uvelicheniju proizvodstva jaic i mjasa pticy na promyshlennoj osnove. Postanovlenie Central'nogo Komiteta KPSS i Soveta Ministrov SSSR ot 26 fevralja $1971 \mathrm{~g}$. [On measures to further increase the production of eggs and poultry meat on an industrial basis. Resolution of the Central Committee of the CPSU and the Council of Ministers of the USSR of February 26, 1971], № 165. Svod zakonov SSSR. Moscow, vol. 7, pp. 517-519. (in Russian).
} 
period, poultry farms operated in the USSR, which gained the fame of the most powerful specialized enterprises of the USSR, in particular, the state farm Krasnyi (Crimea region), poultry farms Yagotinska and Starynska (Kyiv region). The poultry industry of the studied period is characterized by deepening of specialization and concentration of production. The increase in the number of poultry in the USSR, as well as the production of eggs and poultry meat was facilitated by the relevant resolutions of the CPSU Central Committee and the Council of Ministers of the Ukrainian SSR, which regulated a number of urgent organizational measures. Scientific and organizational support of the industrial poultry industry in the Ukrainian SSR of this period was carried out by scientists of the Ukrainian Poultry Research Institute.

Prospects for further exploration are to study the scientific, organizational and socio-economic foundations of poultry development in the Ukrainian SSR in 1971-1990.

\section{SUMMARY}

The purpose of article is to highlight the influence of socioeconomic and organizational factors of the formation and development of the industrial sector of poultry farming in the Ukrainian SSR in 1964-1971. The research methodology is based on the general scientific principles of historical authenticity, objectivity, systemicity, complexity, and scientific. The author used general scientific, interdisciplinary and special historical methods, as well as a diverse source base, which is based on archival documents that reveal the main tendencies of the transfer of poultry farming to an industrial basis.

The scientific novelty of the article is to carry out a holistic analysis of the formation of the industrial sector of poultry farming in the context of socio-economic and organizational factors. The author first has proved that the development of this branch occurred simultaneously with the rise of industry and the increase of gross social product, national income, wages of workers, employees and collective farmers, etc.

It has established that an increase in the urban population in the $60-70$ 's of the 20th century was the prerequisite for the creation of specialized farms of industrial type around the big cities and industrial centres of the Ukrainian SSR - poultry farms for supplying the population with food eggs and poultry meat. It has shown that during 
this period poultry farms operating in the republic, which got the status of the most powerful specialized enterprises of the Ukrainian SSR, functioned in the republic. They included to its the state farm "Krasnyi" (Crimean region), poultry farms "Yagotynska" and "Starynska" (Kiev region). As the main features of the poultry industry of the investigated period, the author considered the specialization and concentration of production. The article demonstrates that the corresponding decisions of the Central Committee of the CPSU and the Council of Ministers of the USSR, which regulated a number of urgent organizational measures, have became the basis for the transition of the branch to the industrial base, contributed to the increase of the poultry stock in the Ukrainian SSR, as well as the production of eggs and meat. The scientific-organizational and scientific-methodological support of the poultry industry in the Ukrainian SSR in 1964-1971 was carried out by scientists of the Ukrainian Research Institute of Poultry Farming.

\section{REFERENCES}

1. Aleksandrov, A. D. (1960) Pticevodstvo vo Francii [Poultry in France]. Pticevodstvo, no. 11, pp. 45-47. (in Russian).

2. Bozhko, P. E. (1963) Pticevodstvo Japonii [Poultry of Japan]. Pticevodstvo, no. № 9, pp. 30-32. (in Russian).

3. V kollektive geroev [In the team of heroes]. (1966) Pticevodstvo, no. 10. S. 2-4. (in Russian).

4. Dahnovskij, N. V. (1959) Intensivnoe pticevodstvo v Soedinennyh Shtatah Ameriki [Intensive poultry farming in the United States]. Moscow, 127 s. (in Russian).

5. Izvestija, (1985). O merah po uvelicheniju proizvodstva $i$ uluchsheniju kachestva kormov. Postanovlenie Central'nogo Komiteta KPSS i Soveta Ministrov SSSR ot 16 ijulja $1970 \mathrm{~g}$. [On measures to increase production and improve the quality of feed. Resolution of the Central Committee of the CPSU and the Council of Ministers of the USSR of July 16, 1970], № 554. Svod zakonov SSSR. Moscow, vol. 7, pp. 530-531. (in Russian).

6. Izvestija, (1985). O merah po dal'nejshemu uvelicheniju proizvodstva jaic i mjasa pticy na promyshlennoj osnove. Postanovlenie Central'nogo Komiteta KPSS i Soveta Ministrov SSSR ot 26 fevralja $1971 \mathrm{~g}$. [On measures to further increase the production of eggs and poultry meat on an industrial basis. Resolution of the Central 
Committee of the CPSU and the Council of Ministers of the USSR of February 26, 1971], № 165. Svod zakonov SSSR. Moscow, vol. 7, pp. 517-519. (in Russian).

7. Izvestija, (1985). Ob organizacii proizvodstva jaic i mjasa pticy na promyshlennoj osnove: Postanovlenie Soveta Ministrov SSSR $i$ Central'nogo Komiteta KPSS ot 3 sentjabrja $1964 \mathrm{~g}$. [On the organization of the production of eggs and poultry meat on an industrial basis: Resolution of the Council of Ministers of the USSR and the Central Committee of the CPSU of September 3, 1964], № 740. Svod zakonov SSSR. Moscow, vol. 7, pp. 512-517. (in Russian).

8. Izvestija, (1985). Ob uvelichenii proizvodstva jaic i mjasa pticy $v$ prigorodnyh zonah krupnyh gorodov $i$ promyshlennyh centrov: Postanovlenie Central'nogo Komiteta KPSS i Soveta ministrov SSSR ot 8 janvarja $1963 \mathrm{~g}$. [On increasing the production of eggs and poultry meat in the suburban areas of major cities and industrial centers: Resolution of the Central Committee of the CPSU and the Council of Ministers of the USSR of January 8, 1963], № 30. Svod zakonov SSSR. Moscow, vol. 7, pp. 519-520. (in Russian).

9. Kirin, I. (1970) Puti uvelichenija proizvodstva mjasa pticy [Ways to increase poultry production]. Pticevodstvo, no. 10, pp. 13-14. (in Russian).

10. Krjazh, I. Z. (1960) Opyt vyrashhivanija mjasnyh cypljat v hozjajstvah Bol'she-Novoselkovskogo rajona [The experience of growing meat chickens in farms Bolshe-Novoselkovsky district]. Pticevodstvo, no. 8. S. 10-13. (in Russian).

11. Marchik, V., \& Bronfman, E. (1970) Brojlernaja fabrika $v$ sodruzhestve s kolhozami [Broiler factory in cooperation with collective farms]. Pticevodstvo, no. 9, pp. 12-13. (in Russian).

12. Meksin, D. (1966) Oni byli delegatami sezda [They were delegates to the convention]. Pticevodstvo, no.6, pp. 6-9. (in Russian).

13. Meljnyk, V. V. (2017) Socialjno-ekonomichni ta politychni peredumovy stanovlennja promyslovogho ptakhivnyctva $v$ USSR (1953-1964). [Socio-economic and political preconditions for the establishment of industrial poultry farming in the Ukrainian SSR (1953-1964)]. Istorija nauky i bioghrafistyka [History of Science and Biography Studies]: elektron. nauk. fakhove vyd, no. 2 URL: http://inb.dnsgb.com.ua/2017-2/07.pd. Accessed 15.04. 2018 (in Ukrainian). 
14. Meljnyk, V. V. (2018) Orghanizacijno-metodychna ta koordynacijna dijaljnistj Ukrajinsjkogho respublikansjkogho specializovanogho trestu ptakhofabryk $i$ ptakhoradghospiv $v$ 1963-1964 rokakh [Organizational-methodical and coordination activity of the Ukrainian Republican Specialized Trust of Poultry Factories and Poultry Farms in 1963-1964]. Istorija nauky $i$ bioghrafistyka [History of Science and Biography Studies]: elektron. nauk. fakhove vyd, no. 3. URL: http://inb.dnsgb.com.ua/2018-3/07.pd. Accessed 25.05. 2018. (in Ukrainian).

15. Meljnyk, V.V. (2018) Naukovo-orghanizacijni zasady rozvytku indykivnyctva $v$ Ukrajinsjkij RSR u drughij polovyni $X X$ stolittja [Scientific and organizational principles of the development of turkey farming in the Ukrainian SSR in the second half of the twentieth century]. Ghileja: naukovyj visnyk, vyp. 135(N 8), pp. 67-71. (in Ukrainian).

16. Meljnyk, V. V. (2018) Naukovo-orghanizacijni zasady rozvytku ghusivnyctva $v$ URSR u drughij polovyni XX stolittja [Scientific and organizational principles of geese farming development in the Ukrainian SSR in the second half of the twentieth century]. Visnyk aghrarnoji istoriji: nauk. Zhurnal, vyp. 23-24, pp. 282-289. (in Ukrainian).

17. Meljnyk, V.V. (2018) Naukovo-orghanizacijni zasady rozvytku kachkivnyctva $v$ Ukrajinsjkij RSR u drughij polovyni $X X$ stolittja. [Scientific and organizational principles of duck farming development in the Ukrainian SSR in the second half of the twentieth century]. Eminak: naukovyj shhokvartaljnyk, no. 4(24), vol. 2, pp. 177-181. (in Ukrainian).

18. Nechaev, N.P. (1966) Poezdka v Kanadu $i$ SShA [Trip to Canada and USA]. Pticevodstvo, no. 3, pp. 32-35. (in Russian).

19. Nikulin, I. P. (1963) Mezhkolhoznye fermy v Kirovskoj oblasti [Inter-farm farms in the Kirov region]. Pticevodstvo, no. 10, pp. 4-5. (in Russian).

20. Oleksenko, G., Anishhenko, V., \& Dalin, V. (1966) Proizvodstvo jaic $i$ ptich'ego mjasa $v$ kolhozah Cherkasshhiny [Production of eggs and poultry meat on collective farms of Cherkasy region]. Pticevodstvo, no. 6, pp. 12-13. (in Russian).

21. Pokid'ko, A.I. (1963) Pticeferma "Rodina” [Poultry Farm Motherland]. Pticevodstvo, no. 10, pp. 6. (in Russian). 
22. Poplevkin, T. (1970) Mjasnoe pticevodstvo Ukrainy na pod'eme [Ukrainian meat poultry farming on the rise]. Pticevodstvo, no. 9 , pp. 2-3.

23. Pushkarenko, V., Lilevman, V. (1966). Kletochnaja batareja dlja vyrashhivanija utjat do 10 dnej [Cage battery for duckling for up to 10 days]. Pticevodstvo, no. 3, pp. 27-29. (in Russian).

24. Samoletov, A. I., \& Karavaev, A. M. (1960). Kletochnoe soderzhanie kur-nesushek na Tomilinskoj pticefabrike [Cage content of laying hens at Tomilinsky poultry farm]. Pticevodstvo, no. 8, pp. 6-10. (in Russian).

25. Sergeev, V. (1966). Iskusstvennoe osemenenie utok v Japonii [Artificial insemination of ducks in Japan]. Pticevodstvo, no. 10, pp. 33-35. (in Russian).

26. Sergeev, V., Popov, A. (1970). Proizvodstvo mjasa brojlerov na kolhoznyh fermah [Production of broiler meat on collective farms]. Pticevodstvo, no. 9, pp. 14-15. (in Russian).

27. Statistika, (1965). Narodne ghospodarstvo Ukrajinsjkoji RSR v 1964 roci: statystychnyj shhorichnyk [People's economy of the Ukrainian SSR in 1964: statistical yearbook]. Kyiv, 694 s. (in Ukrainian).

28. Statistika, (1966). Narodne ghospodarstvo Ukrajinsjkoji RSR v 1965 roci: statystychnyj shhorichnyk [People's economy of the Ukrainian SSR in 1965: statistical yearbook]. Kyiv, 715 s. (in Ukrainian).

29. Statistika, (1974). Narodnoe hozjajstvo Ukrainskoj SSR v 1973 godu: statisticheskij ezhegodnik [People's Economy of the Ukrainian SSR in 1973: a statistical yearbook]. Kiev, 584 s. (in Russian).

30. Statistika, (1976). Narodnoe hozjajstvo Ukrainskoj SSR v 1975 godu: statisticheskij ezhegodnik [People's Economy of the Ukrainian SSR in 1975: a statistical yearbook]. Kiev, $540 \mathrm{~s}$. (in Russian).

31. Forum pticevodov [Forum poultry breeders]. (1966). Pticevodstvo, no. 5, pp. 10-11. (in Russian).

32. Hachirashvili, G., \& Shperling, M. (1966) Ukrepljat' tehnologicheskuju disciplinu, povyshat' rentabel'nost' proizvodstva [Strengthen technological discipline, increase the profitability of production]. Pticevodstvo, no. 1, pp. 7-9. (in Russian). 
33. Hachirashvili, G., \& Shperling, M. (1966) Kul'tura proizvodstva - osnova uspeha [The culture of production is the basis of success]. Pticevodstvo, no. 10, pp. 4-9. (in Russian).

34. Centraljnyj derzhavnyj arkhiv vyshhykh orghaniv vlady [Central State Archive of the Supreme Power and Administration of Ukraine], f. P-4861, d. 1, c. 2139, pp. 84-89. (in Ukrainian).

35. Centraljnyj derzhavnyj arkhiv vyshhykh orghaniv vlady [Central State Archive of the Supreme Power and Administration of Ukraine], f. P-2, d. 13, c. 5088, pp. 72-75. (in Ukrainian).

36. Shajtan, B. I., \& Polishhuk, P. N. (1960) Organizacija pticevodstva $v$ kolhoze "Kolos" [The organization of poultry farming at collective farm Kolos]. Pticevodstvo, no. 5, pp. 4-10. (in Russian).

\section{Information about the author:}

Victoriia Melnyk,

Candidate of Agricultural Sciences, Associate Professor,

National University of Life and Environmental Sciences of Ukraine 15, Heroyiv Oborony str., Kyiv, Ukraine ORCID ID: orcid.org/0000-0003-2491-757X 